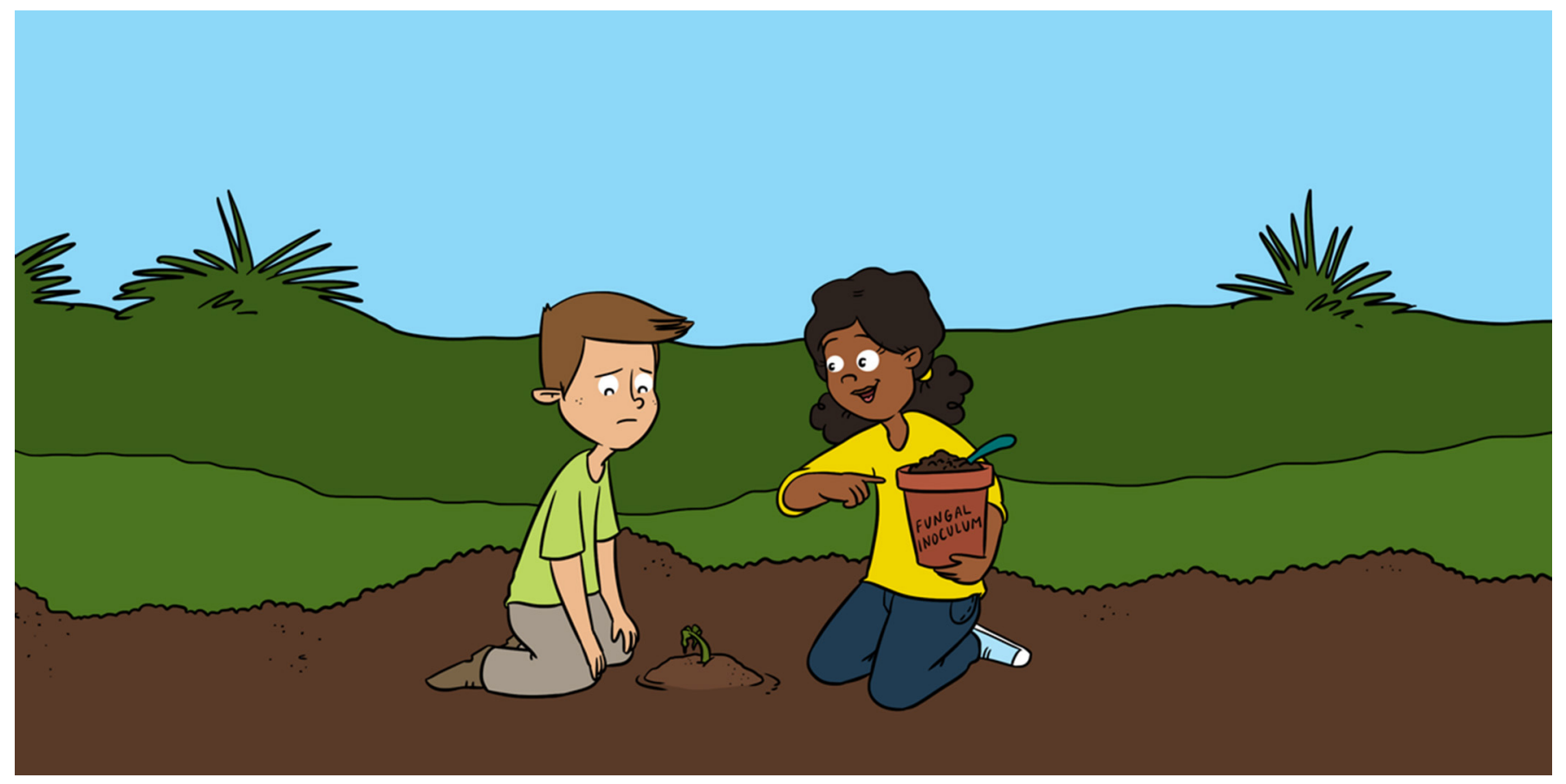

\title{
TINY FUNGI IN THE SOIL ARE LIKE MEDICINE FOR NATURE
}

\section{Lena Neuenkamp ${ }^{1 *}$ and Nadia I. Maaroufi ${ }^{1,2}$}

\section{${ }^{1}$ Institute of Plant Sciences, University of Bern, Bern, Switzerland}

${ }^{2}$ Department of Forest Mycology and Plant Pathology, BioCenter, Swedish University of Agricultural Sciences (SLU), Uppsala, Sweden

YOUNG REVIEWERS:

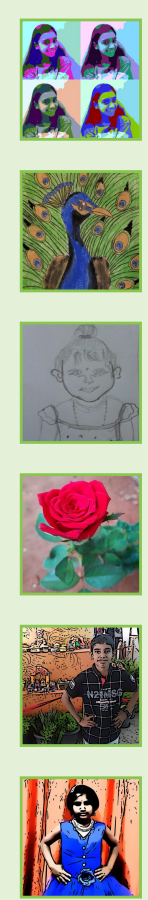

VETRIVEL

AGE: 12
Like humans, plant and animal species have a specific type of place, called an ecosystem, where they prefer to live. If the ecosystem changes too much, some species will disappear, much the same way people avoid living in the desert because it is too hot and dry. Humans modify many ecosystems, sometimes so severely that almost no plants or animals can live there anymore. To help damaged ecosystems recover, we often start by planting trees or other plants. Biologists found that mycorrhizal fungi, tiny fungi living in the soil and inside plant roots, could speed up ecosystem recovery by making plants grow back faster and stronger. In this article, we describe how the recovery of ecosystems can be enhanced by mycorrhizal fungi, and when mycorrhizal fungi are especially helpful. 


\section{ECOSYSTEM}

An environment colonized by different organisms that are living together and interacting with each other.

\section{DEGRADED}

ECOSYSTEM

An ecosystem that has been damage or destructed, which also negatively affects the organisms living in the ecosystem and hampers the functioning of the ecosystem.

\section{ECOLOGIST}

A scientist that studies how ecosystems function, and how the organisms in an ecosystem interact with each other and the environment.

\section{DEGRADED ECOSYSTEMS NEED OUR HELP}

Natural ecosystems, such as forests, grasslands, or bogs-provide many functions and serve as homes for native plants, animals, and tiny microorganisms in the soil. Some ecosystems also filter and store water, keep excess carbon out of the atmosphere, and preserve a healthy soil layer where plants can grow and produce fruits and vegetables for us to eat. Ecosystems provide these functions if they are healthy and intact, but sometimes ecosystems become disturbed and stop functioning well. Such disturbances include fires, floods, or tree fall after storms. Fortunately, healthy ecosystems can usually recover easily from these disturbances. However, if disturbances occur frequently over a long period, or if they are very intense, ecosystems have more difficulty recovering and might change. For example, a forest might become a grassland after a very intense storm pulls all the trees over. As another example, after a long period of drought (when there is not enough water for plants to survive) plants may have a hard time growing back even when water is available again. If, after disturbances, ecosystems change to become less complex and have fewer species living in them, we call them degraded ecosystems.

Humans use ecosystems to create space for cities, to produce food in agricultural fields, or to mine for stones, sand, or metals for building or manufacturing. These human activities often disturb ecosystems so severely and for so long that the ecosystems are pushed over the edge from where they can no longer recover without help. Ecologists, which are scientists who study how ecosystems function and can be home to many species, can help restore degraded ecosystems, helping them to regain their health and their functions. When ecologists restore ecosystems, they might plant trees to help forest recovery after trees are cut down for timber production, or sow seeds to help grasslands recover after they have been used as agricultural fields. Even with this help, sometimes the new plants do not grow well, or the ecosystem looks different after restoration than it did before the disturbance. Why does restoration sometimes not work as well as other times? Recently, ecologists have begun to understand that successful ecosystem restoration needs to take care of both the plants and animals aboveground and the organisms that live belowground, in the soil.

\section{WHY ARE THE SMALL CREATURES LIVING IN THE SOIL SO IMPORTANT?}

Because plants cannot move, they use their roots to look for nutrients and water in the soil. The soil is an important part of the ecosystem and is the habitat of many small creatures [1]. One teaspoon of soil is inhabited by more organisms than there are people on earth-around 7.5 billion [2] (Figure 1A)! All these small creatures interact with each other and contribute to the functioning of the ecosystem, so the health 
Figure 1

The small creatures inhabiting the soil. (A) Microscope pictures of bacteria, fungi, mites, nematodes, and springtails. Nematodes are small roundworms, mites look a bit like mini spiders, and springtails are tiny insects that sometimes can jump (Photo credits: Mehdi Maaroufi, Nadia I.

Maaroufi and Arne Fjellberg). (B) Pictures of different types of mycorrhizal fungi and their host plants. (1) An orchid and the orchid mycorrhizal fungi inside the plant root. (2) Arbuscular mycorrhizal fungi inside a blueweed plant. (3) A heather plant and ericoid mycorrhizal fungi inside the plant root. (4) A pine tree and ectomycorrhizal fungi on the surface of the plant root (Photo credits: Lena

Neuenkamp, Petr Kohout, Jane Oja, Javi Puy).

\section{DECOMPOSERS}

Organisms that feed on dead plant and animal material, and by that break this material down into the different nutrients it is made off until it becomes soil again. Plants, in turn, take up the nutrients in the soil as food. Many decomposers are fungi.

\section{PATHOGENS/ PATHOGENIC FUNGI}

Organisms that cause diseases for example a pathogenic fungus that makes plant leaves turn brown and incapable of doing photosynthesis.
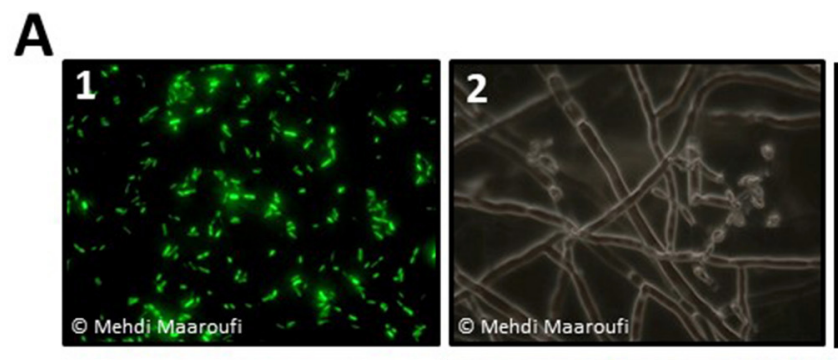

\section{Bacteria \\ 2. Fungi \\ 3. Mites \\ 4. Nematode \\ 5. Springtails}

B
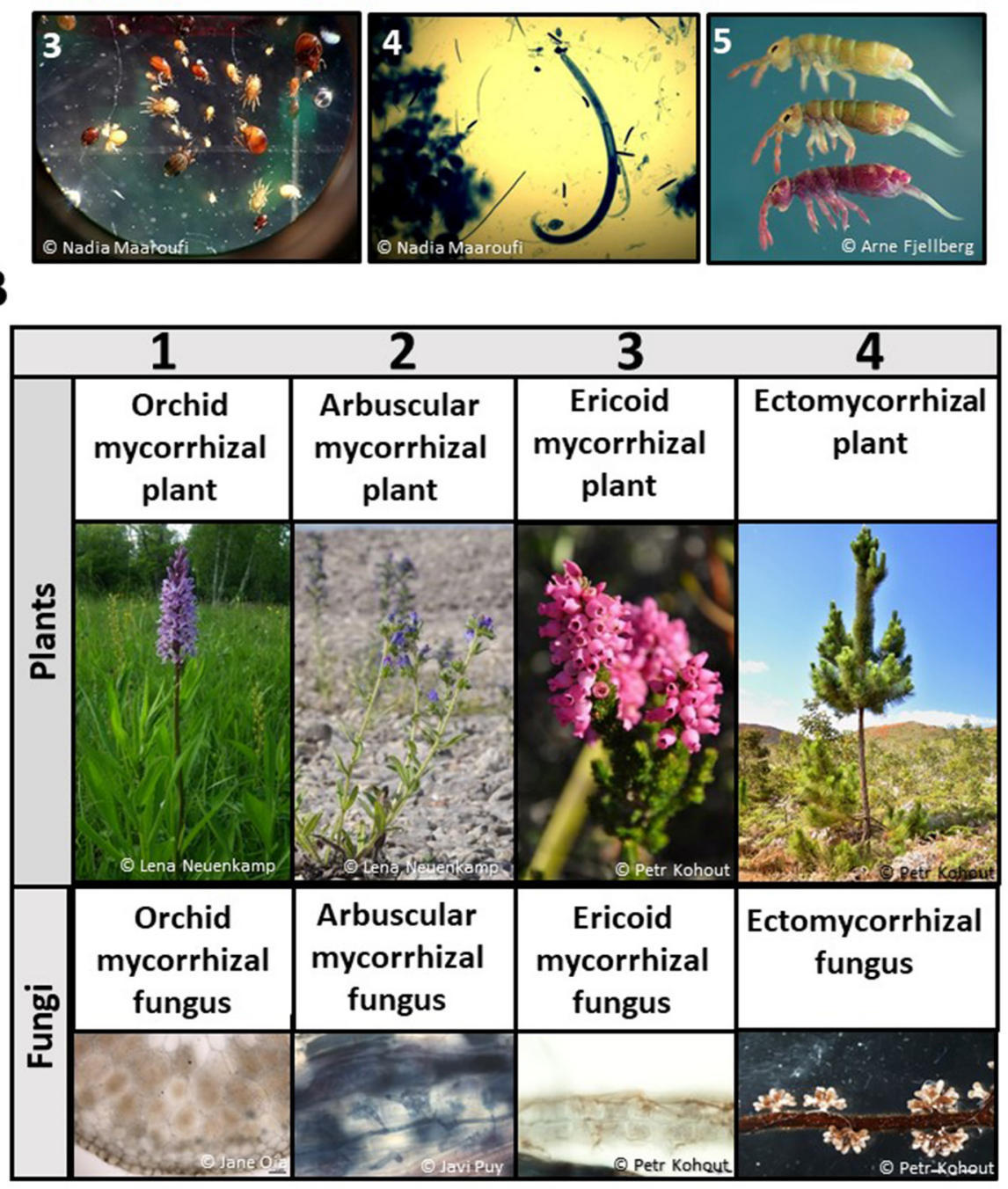

Figure 1

of these soil organisms is likely to be quite important for ecosystem restoration. The most abundant soil organisms are bacteria and fungi. Some of them, called decomposers, feed on dead plants and help to break down the plant material until it becomes soil again [3]. Some soil organisms, called pathogens, can attack plant roots and make plants sick. Other soil organisms, called symbionts, cooperate with plants by exchanging nutrients with them. Mycorrhizal fungi are one group of symbionts that researchers believe may help with ecosystem restoration $[4,5]$ (Figure 1B). 


\section{SYMBIONTS/}

SYMBIOTIC FUNGI

Organisms that live together and help each other. For example, symbiotic fungi, such as mycorrhizal fungi that live in plant roots and help plants with nutrient uptake from the soil in exchange for carbon produced by plants in their leaves.

\section{MYCORRHIZAL}

FUNGI

(MI-CO-RYE-Z-ALL FUN-GUY)

A group of fungi that live in the soil and the roots of plants. Mycorrhizal fungi help the plants with nutrient uptake and resistance against drought or disease caused by other fungi, and in return fungi get food from the plants.

\section{SOIL INOCULATION}

Adding soil organisms (for example, mycorrhizal fungi or bacteria) to the soil to make plants grow better

\section{MYCORRHIZAL FUNGI ARE LIKE POWERFUL MEDICINE FOR PLANTS}

Mycorrhizal fungi can help plant roots to collect more nutrients and water from the soil, therefore helping the plants to grow better. So, let us call them helper fungi from now on. In addition, these helper fungi can protect plants against pathogens that can cause plant diseases! In return for the benefits helper fungi provide, plants give helper fungi some of their carbon-a nutrient that plants produce with the help of sunlight during photosynthesis. So, the partnership between plants and fungi is a win-win situation for both partners, called symbiosis. Ecologists tested the effects of the helper fungi for assisting ecosystem restoration (Figure 2). The process of adding helper fungi to the soil is called soil inoculation. Studies testing the effects of soil inoculation on ecosystem restoration showed that replanted tree seedlings and grasses grew better when helper fungi were added to the soil [4]. In addition, the studies showed that grasslands restored by adding helper fungi were richer in plant species.

\section{THE POWER OF HELPER FUNGI VARIES}

Different types partnerships exist between helper fungi and plants, depending on which species of fungi are most abundant in a specific ecosystem (Figure 1B). Plants and helper fungi differ in when and how much they need each other and how fairly they trade resources and benefits with each other. So, restoration of ecosystems with plants that depend strongly on helper fungi might need mycorrhizal fungi as a medicine more than other ecosystems in which the plants are more independent from helper fungi [5]. When scientists looked through all ecosystem restoration experiments that used helper fungi, they actually did find that the benefits of adding helper fungi varied between studies [4]. So, helper fungi are a good medicine for plants, but when they are most powerful depends on the plants and the ecosystem.

The scientists concluded that helper fungi were the most helpful in the following three conditions:

- for plants that give shelter to bacteria in their roots, making the plants hungry enough for two-themselves and the bacteria (like pea or bean plants);

- for plants that have trouble finding nutrients because their roots are too big to reach into the small soil pores where many nutrients are sitting (like some grasses); and

- for plants growing on soils that are both severely disturbed and nutrient-poor. 
Figure 2

Examples of results of ecosystem restoration projects using mycorrhizal fungi. (A) Heathland restoration in the Netherlands, with the aim of

re-establishing a heathland on an old agricultural field with the help of heather plants and ericoid mycorrhizal fungi. (B) Limestone quarry restoration in Estonia, with the aim of speeding up revegetation of an abandoned limestone quarry with the help of grassland seeds, hay, and arbuscular mycorrhizal fungi (Photo credits: Jasper Wubs, Tanel Vahter).

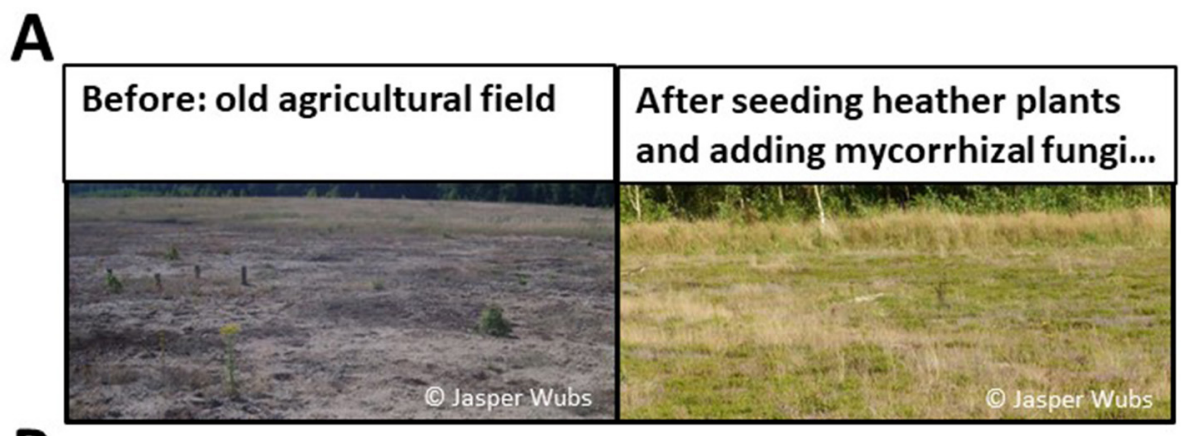

B

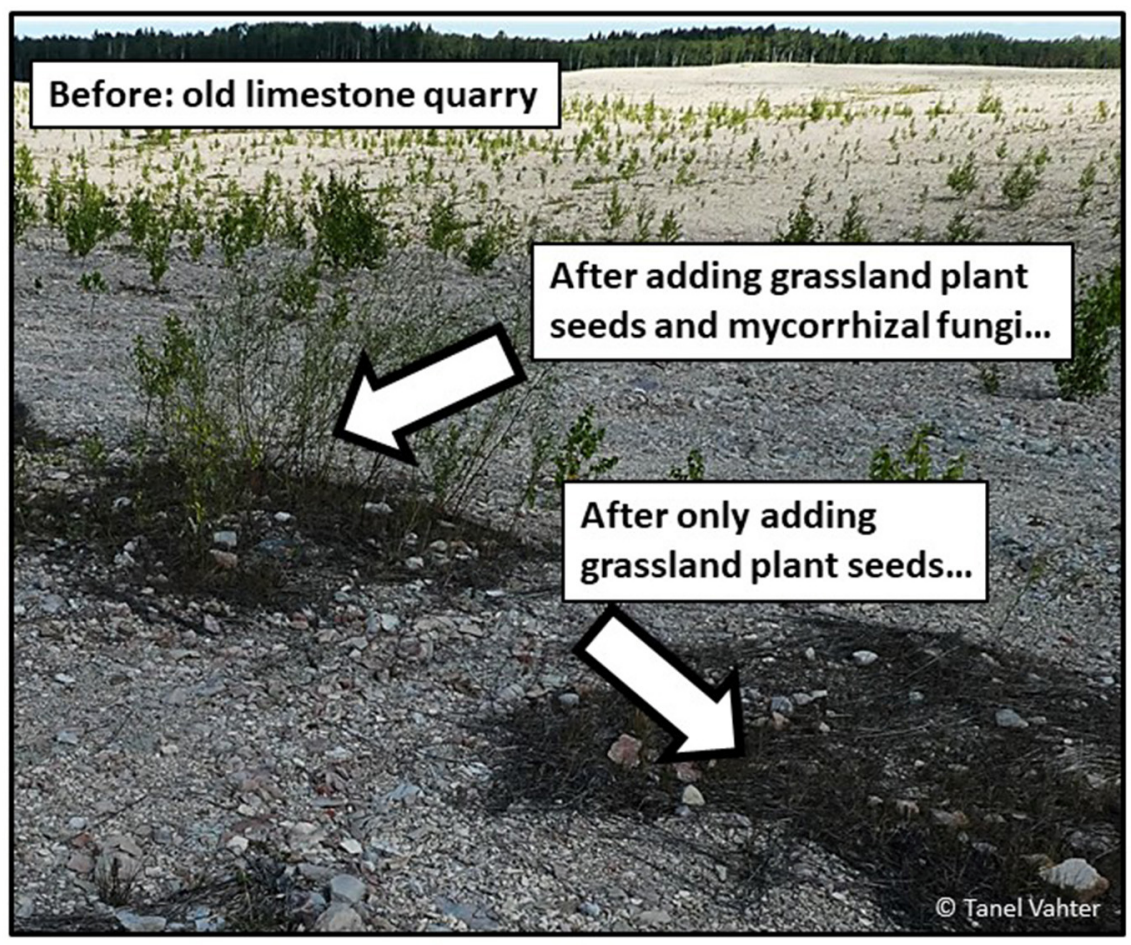

Figure 2

\section{WANT TO HELP YOUR OWN HOUSE PLANTS?}

About $80 \%$ of all plants-even your potted plants at home-have a symbiosis with one type of helper fungi, called arbuscular mycorrhizal fungi. You can keep your plants healthy by making your own arbuscular mycorrhizal fungal inoculum (Figure 3). Many gardeners already do this! You will need a shovel, a 10-liter bucket to mix the soil, 3-5I of sand, seeds of grass and clover plants, and 4-6 flowerpots.

The steps:

- Plant selection: Select one or two plants from your garden that form arbuscular mycorrhizal symbioses (maybe a grass and a clover plant) and dig them out together with a good portion of soil around the roots. 
Figure 3

Do-it yourself mycorrhizal inoculum. The most important steps for producing your own mycorrhizal inoculum (Based on the instructions given here: https://orgprints. org/35308/1/ symanczik-etal2018-Mycorrhizalfungi-as-naturalbiofertilizer_ technical_note.pdf).

\section{BAIT PLANTS}

Plants used as a lure to attract mycorrhizal fungi in their roots, where mycorrhizal fungi reproduce and grow. The multiplied fungal material in the roots and the surrounding soil can then be used to produce a fungal inoculum.

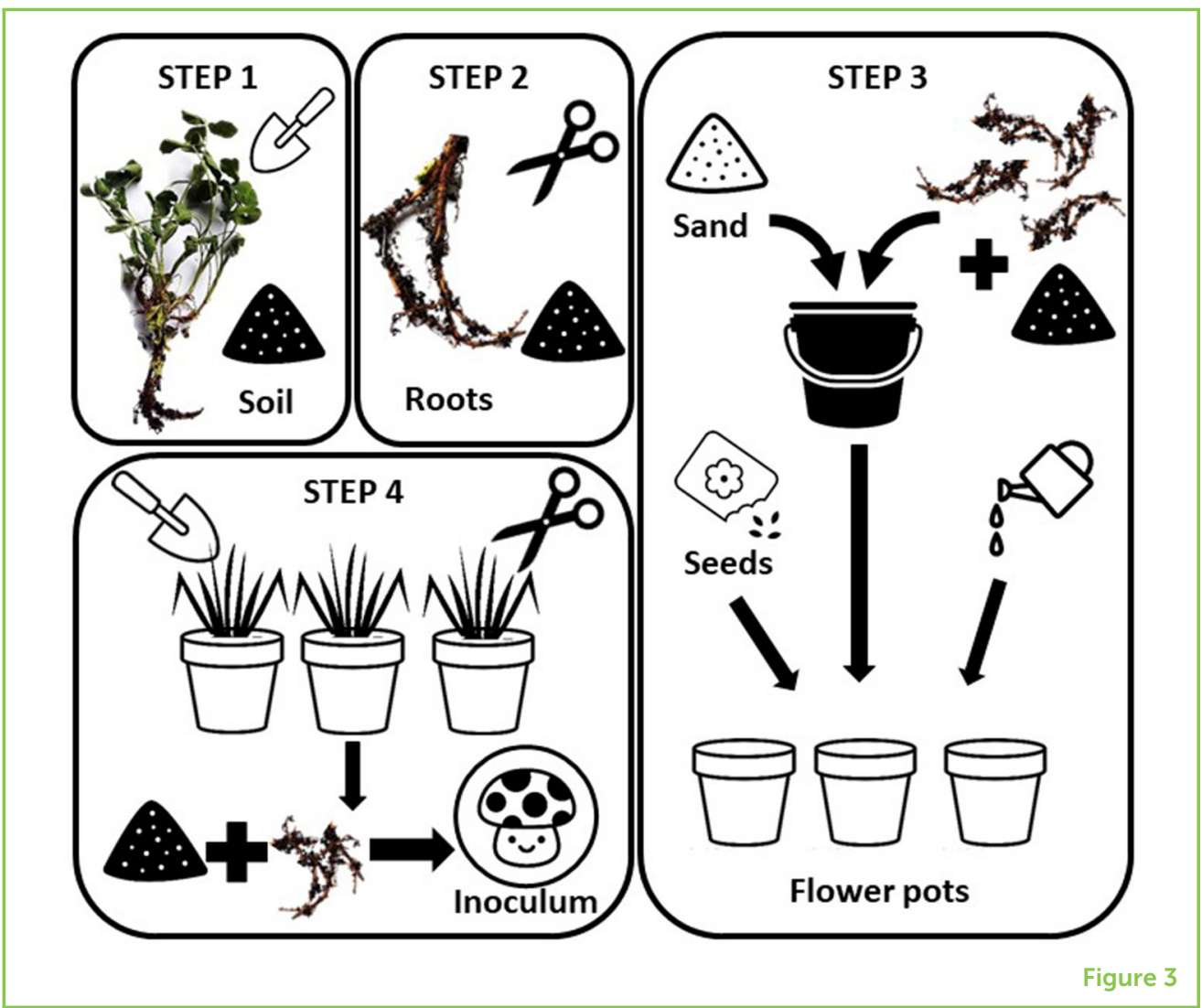

- Source inoculum: Remove the leaves and stems of both plants, cut their roots into small pieces, and mix all roots and soil well. This is your source inoculum, which we will multiply so that we do not have to dig out too many garden plants to create the inoculum.

- Inoculum multiplication: Mix the source inoculum with sand (1 part of inoculum with 1 part of sand, or even 1 of part inoculum with 2 parts of sand) and put it into the flowerpots. Add the grass and clover seeds to the pots, water them, and let them grow for 2-4 months. The seeded species are called bait plants because they attract the arbuscular mycorrhizal fungi. When the bait plants start growing, the arbuscular mycorrhizal fungi will colonize their roots and the fungal population will grow. The longer the plants grow, the more fungi will be in the soil.

- Inoculum harvest: After 2-4 months, remove all leaves from the bait plants, cut their roots into small pieces, and mix them with the soil. The inoculum is now ready to be added in small amounts to your potted plants-either dry or mixed with water.

\section{TAKE HOME MESSAGE}

Human activities can degrade ecosystems so severely that they need help to recover. Mycorrhizal fungi are helper fungi for plants that could support ecosystem recovery, because they can increase 
plants' nutrient uptake and protect plants against diseases or drought. Different types of helper fungi exist with different properties, thus when and which helper fungi are most powerful for ecosystem recovery depends on the plants and the ecosystem.

\section{AUTHOR CONTRIBUTIONS}

LN and NM conceived the original idea and wrote the first draft of the manuscript. All authors gave final approval for submission.

\section{REFERENCES}

1. Maaroufi, N. I., and De Long, J. R. 2020. Global change impacts on forest soils: linkage between soil biota and carbon-nitrogen-phosphorus stoichiometry. Front. For. Glob. Change 3:16. doi: 10.3389/ffgc.2020.00016

2. Available online at: http://www.soil-net.com/ (accessed November 06, 2020).

3. Maaroufi, N. I., Nordin, A., Palmqvist, K., Hasselquist, N. J., Forsmark, B., Rosentstock, N. P., et al. 2019. Anthropogenic nitrogen enrichment enhances soil carbon accumulation by impacting saprotrophs rather than ectomycorrhizal fungal activity. Glob. Change Biol. 25:2900-14. doi: 10.1111/gcb.14722

4. Neuenkamp, L., Prober, S. M., Price, J. N., Zobel, M., and Standish, R. J. 2019. Benefits of mycorrhizal inoculation to ecological restoration depend on plant functional type, restoration context and time. Fungal Ecol. 40:140-9. doi: 10.1016/j.funeco.2018.05.004

5. Neuenkamp, L., Moora, M., Öpik, M., Davison, J., Gerz, M., Männistö, M., et al. 2018. The role of mycorrhizal type and status in modulating the relationship between plant and arbuscular mycorrhizal fungal communities. New Phytol. 220:1236-47. doi: 10.1111/nph.14995

SUBMITTED: 30 April 2020; ACCEPTED: 30 October 2020; PUBLISHED ONLINE: 30 November 2020.

EDITED BY: Helen Phillips, German Centre for Integrative Biodiversity Research (iDiv), Germany

CITATION: Neuenkamp L and Maaroufi NI (2020) Tiny Fungi in the Soil Are Like Medicine for Nature. Front. Young Minds 8:557383. doi: 10.3389/frym.2020.557383

CONFLICT OF INTEREST: The authors declare that the research was conducted in the absence of any commercial or financial relationships that could be construed as a potential conflict of interest.

COPYRIGHT () 2020 Neuenkamp and Maaroufi. This is an open-access article distributed under the terms of the Creative Commons Attribution License (CC BY). The use, distribution or reproduction in other forums is permitted, provided the original author(s) and the copyright owner(s) are credited and that the original publication in this journal is cited, in accordance with accepted academic practice. 

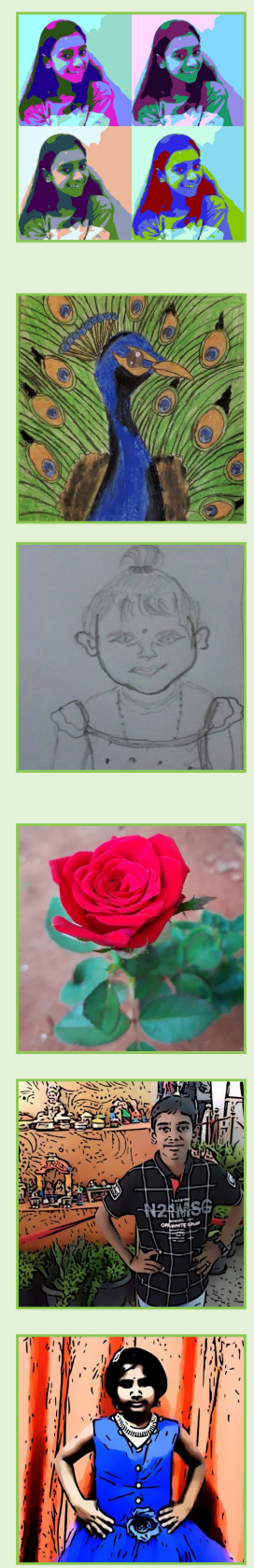

YUTHIGA, AGE: 8

I am interested in painting and playing chess. I won third prize and got trophy at district level chess tournament. My favorite subjects are English, Science, and Mathematics. I spend my holidays exploring new things.

\section{AUTHORS}

\section{LENA NEUENKAMP}

I am a plant ecologist, and I started to investigate the soil because it could help me to understand plants. Well, I then became fascinated by mycorrhizal fungi and how they interact with plant roots. I am working as a researcher at the University of Bern in Switzerland. I am interested in understanding how human disturbances and climate change influence plant and soil communities, as well as the interactions between plants and soil organisms. I would like to use that knowledge to predict how 
well ecosystems can function and provide services to humans, in the face of current human disturbances and climate change. *lena.neuenkamp@ips.unibe.ch

\section{NADIA I. MAAROUFI}

I am a soil ecologist interested in the small creatures inhabiting the soil. I am working both at the University of Bern in Switzerland and at the Swedish University of Agricultural Sciences, Uppsala in Sweden. I am particularly interested in understanding how soil organisms are impacted by human and natural disturbances, and how these disturbances affect forest and grassland ecosystem functioning. 